\title{
INTERNATIONAL LAW: IMPLICATIONS FOR EXPLOITATION OF DEEP-SEA BENTHIC BIODIVERSITY
}

\author{
By Patricia Kraniotis and Roger B. Griffis
}

$\mathrm{T}$ HERE IS INCREASING INTEREST in the profusion of living resources dwelling on and in the ocean floor, from scientific interest in what is there and why life is so diverse, to interest in the potential for commercial exploitation. Although recent estimates of the number of species on the deep ocean floor (10-100 million) remain the subject of intense debate. even the lower estimates are hundreds of times higher than older projections and reflect clear recognition that the deep-sea benthos is far more diverse than expected (Grassle and Maciolek. 1992; May, 1992; Poore and Wilson, 1993; National Research Council. 1995). These findings have challenged current perceptions and theories about how species diversity is produced and maintained. because the deep sea was perceived as having relatively few environmental barriers. usually considered important for the evolution of new species. The genetic and chemical diversity of these organisms also means that they have great potential commercial value. For example, bacteria living near thermal vents on the ocean floor have yielded the second generation of heat-stable enzymes for use in amplifying small quantities of DNA from clinical, environmental and forensic samples. with potentially great economic value (National Science and Technology Council, 1995). In the ocean, these vents are found primarily in the deep sea-bed areas beyond the jurisdiction of coastal states (Glowka. 1995).

P. Kraniotis. Office of General Counsel International Law), National Oceanic and Atmorpheric Administration, Rm. 7837. 14th and Constitution NW. Washington. DC 20230. USA. R.B. Griffis, Office of Policy and Strategic Planmmg, National Oceanic and Atmospheric Administration. Rn. 6117. 1. 4th and Constitution NW, Washington, DC 20230. USA.
Both research and commercial interests in occan biodiversity have raised concerns, particularly among developing nations, about access to genetic resources, profits from exploitation, and efforts to conserve these resources. Two international conventions, the United Nations Convention on the Law of the Sea (UNCLOS) and the Convention on Biological Diversity (CBD), are relevant and may have differing implications for research and exploitation of these resources. In fact, the Second Conference of Parties to the CBD. held in Jakarta in November 1995, called for consultation with the United Nations Office of Ocean Affairs and the Law of the Sea to examine the relationship between these two international conventions regarding conservation and sustainable use of genetic resources of the deep sea-bed. The CBD parties viewed this as a necessary first step in gaining an understanding of the various scientific, technical, and technological issues associated with valuable genetic and biochemical resources of the deep sea-bed. This essay briclly discusses both conventions and their possible implications for future research and bioprospecting.

United Nations Convention on the Law of the Sea. which entered into force on 16 November. 1994, is a comprehensive framework agreement governing uses of the occan. The United States, although not yet a party. recognizes much of UNCLOS as reflecting customary international law. In July 1994 the United States signed and is provisionally applying an agreement modifying the UNC LOS deep sea-bed mining provisions. Both documents are before the U.S. Senate for its advice and consent. Among other matters, UNCLOS governs both marine scientific research and exploitation of marine resources in areas within and beyond national jurisdiction. It establishes the 200-mile exclusive economic zone (EEZ) within which a coastal state has sovereign rights over its resources (both living and nonliving). For living resources that dwell on and in the sea-bed, the phrase "areas of national jurisdiction" includes the territorial sea, EEZ, and continental shelf. In the ocean area beyond the areas of national jurisdiction, UNCLOS provides to all states the freedom to exploit the living marine resources of the ocean and sea-bed and prohibits any state from claiming sovereignty or sovereign rights over these resources. UNCLOS also embodies the principle of freedom of marine scientific research both within the EEZ and beyond it. Although scientific research within the EEZ is subject to coastat state regulation, beyond the EEZ it is not.

United Nations Convention on the Law of the Sea treats living and nonliving (i.e., mineral) marine resources differently. Both living and nonliving resources are subject to coastal state jurisdiction in areas of national jurisdiction. For the sea-bed that lies beyond national jurisdiction. referred to as "the Area." UNCLOS establishes a regime governed by a "Sea-bed Authority." that applies to mineral resources. UNCLOS declares the mineral resources of the Area to be the "common heritage of mankind" and establishes a complex mechanism whereby the community of nations may have some share in any benefits reaped from sea-bed mining.

By contrast, the living marine resources that lie beyond areas of national jurisdiction may be exploited freely by any nation. although there is a duty to practice conservation. No equivalent system is established for any sharing of benetits reaped from the living resources of the areas beyond national jurisdiction. 
including resources of the Area. UNCLOS does not single out genetic resources for differing treatment. As such, genetic resources would fall within the general category of living marine resources and treated accordingly (Burke, 1994).

Although genetic resources of the Area are not included within the category of resources that UNCLOS refers to as the "common heritage of mankind," some have raised the possibility of exploring the pros and cons of developing a legal regime that affords genetic resources similar treatment (Glowka, 1995). This, in turn, raises the question of the applicability of the CBD because it addresses access to genetic resources and sharing of the benefits derived from them.

The CBD entered into force on 23 December, 1993. Its basic objectives are the conservation of biological diversity, sustainable use of its components, and fair and equitable sharing of benefits arising out of the utilization of genetic resources. The obligations of CBD parties with respect to the components of biodiversity, including obligations concerning access to genetic resources and the sharing of benefits from those resources, apply within the limits of national jurisdiction (i.e., the territorial waters, EEZ. and continental shelf) of a coastal state, but not beyond. For this reason, the relevance of the CBD to bioprospecting lies primarily within-rather than beyond-areas national jurisdiction (Burke, 1994). With respect to the marine environment, the $C B D$ requires parties to implement its obligations consistently with UNCLOS. In that sense, the two conventions may be read as in harmony with each other in their treatment of marine resources.

Under both conventions a coastal state might impose conditions on those nations desiring access to the resources within its national jurisdiction. For example, under the CBD a party might allow access to its genetic resources in exchange for sharing benefits derived from their use (for additional information on this topic see WRI, 1993). Under UNCLOS a coastal state may restrict or even preclude exploitation of the resources found in its EEZ and on its continental shelf. By contrast, neither convention restricts access to genetic resources beyond zones of national jurisdiction. Another important similarity between the two conventions is that both call for nations to cooperate with respect to conservation in areas beyond national jurisdiction.

With respect to marine scientific research. the two conventions are also compatible. The CBD calls for international technical and scientific cooperation and information sharing. As to the marine environment, it calls for parties to cooperate, directly and through international organizations, regarding areas beyond national jurisdiction.

UNCLOS establishes a comprehensive and detailed legal framework for marine scientific research both within and beyond areas of national jurisdiction. It recognizes the right to conduct research and emphasizes international cooperation. sharing data, and strengthening the research capabilities of developing states. Of the two. UNCLOS provides the more specific and detailed regime for marine scientific research, including the deep sea-bed areas beyond national jurisdiction. As such, there is a strong case that UNCLOS is the appropriate legal framework for fostering such research and, at the same time, taking steps to conserve these little understood and potentially valuable resources.

Relatively little is known today about the living marine resources of the deep sea-bed. Scientific research in this area, although in its incipient stages, is clearly important for its own sake. Any commercial development of these resources (genetic and other) will take time and resolution of questions concerning collection techniques, ecological impacts, legal im- plications, compound isolation, and product development, given the extreme conditions encountered during the collection process and the lengthy process involved in commercial development of bioproducts (see Fenical, 1996, this issue). Whether or not this science may, at some point in the future, lead to commercial exploitation, research on deepsea benthic biodiversity will make important contributions to our knowledge of the planet.

\section{References}

Burke. W.T. 1994: State Practuce. Nen Oerem Use's and Oesean Golestance Under UNCLOS 13. Paper presented to the 28th meeting of the law of the Sea Institute. Honolulu. HI, 11-1+ July. 1994.

Fenical, W. 1996: Marine biodersersty and the medicine cabinet the status of new drugs from marine organisms. Occeonogrephly, ", $23-27$.

Glowka. L. 1995: The Deepest of Irones: Genetic Resularces, Marine Sicintitu Research and the Internatisnal Decep Seat-Bed Area. Paper distributed for comment and discussion at the First Meeting of the Subsidiary Body on Scientific. Technical and Technological Advice of the Conventoon on Biodiversity. Patris, + September. 1995.

Grassle, J.F. and N.J. Maciolek, 1942: Deep-seia species richness: regional and local diversity estimates from quantitative bottom samples. Amer. Nat., 139. 313-341.

May. R.M. 1992: Bottoms up for the oceans. Netture, 357, 278-279.

National Research Council (NRC), 1995: Understanding Marine Biodiversity: A Research Agenda for the Nation. National Academy Press, Washington, DC.

Nattional Science and Technology Council (NSTC, 1995: Opportunities in marine biotechnology and aquaculture. In: Biotechnology for the 2lst Contury: Nell Horizons. Report from the Biotechnology Revearch Subcommittce. Committee on Fundamental Science. U.S. Government Printing Office. Washington. DC

Poore. G.C.B. and G.D.F. Wilson. 1993: Marme species richness. Nature, 367. 597-594.

World Reyources Institute (WRI). 1993: Biodiversity Prospecting: Gutedeliness for U/sing Ge' netic and Biochemical Resources Sustanably and Equitubly: Contribution to the WRI/UCN/UNEP Global Biodiversity Strat egy. Washington, DC. : 